\title{
The Adoption of New Technology: Conceptual Model and Application
}

\author{
Miriam Christi Midori Oishi Nemoto', Eduardo Pinheiro Gondim de Vasconcellos², \\ Reed Nelson ${ }^{3}$
}

\begin{abstract}
The decision to adopt a new technology or not depends on the benefits to be gained by incorporating new technical, functional or esthetic solutions, in order to attain the company's competitive positioning; this decision also depends on the costs and risks involved. In general terms, businesses lack the resources, whether financial, human, or structural, to innovate or even to adapt new technologies. The objectives of this study are to test an innovation adoption model on a real case and show the importance of international cooperation for new technology implementation processes, based on a decision-making case about whether or not to adopt a new technology that occurred in eletronic company in Brazil (called "A"). The new technology might help to solve certain challenges the company faced in its printer plant, by increasing efficiency and cutting costs.
\end{abstract}

Keywords: RFID; innovation networks; supply chain; technological cooperation.

\footnotetext{
' UNISA - School of Account and Business Administration - University of Santo Amaro. Rua Isabel Schmidt 349, Santo Amaro, São Paulo - SP - CEP 04743-030, Brazil. Tel.: 55-I I-8I039028. E-mail: miriamoishi@yahoo.com.br

${ }^{2}$ FEA - USP - School of Economics and Business Administration - University of São Paulo. Av. Prof. Luciano Gualberto , 908, Cidade Universitária. São Paulo - SP - CEP 05508900, Brazil. Tel.: 55-I I- 38 I 84037 (R: 5837) Fax: 55-I I- 309 I 5837.

E-mail: epgdvasc@gmail.com

${ }^{3}$ Southern Illinois University Carbondale - Department of Management. Rehn Hall 2I4 - Mail Code 4627. 1025 Lincoln Drive. Carbondale, Illinois 6290I, USA. Tel.: 618.453.3307 Fax:618.453.7835. E-mail: renelson@siu.edu
} 


\section{Introduction}

The " $A$ " is the $14^{\text {th }}$ company in the Fortune magazine list; it operates in over 170 countries and has 156,000 employees, 70,000 service partners and 145,000 sales partners; its annual sales amount to US\$ 100.5 billion, according to data from the quarter ended in July 2007.

In Brazil, the firm has two plants, three distribution centers and roughly 2,500 people in its operations; it also provides employment, indirectly, for another 5,000 to 7,000 people. Its average production totals some three million units/yr in the Mercosur area and neighboring countries (Chile, Peru and Colombia).

"A" is the company with the greatest industrial supply chain in the world; it ranks $9^{\text {th }}$ in terms of non-military supply chain in the world, $I^{\text {st }}$ in the use of material, $I^{\text {st }}$ in manufacturing/ODM contracts, $I^{\text {st }}$ in buying in the electronic industry and has over one billion customers worldwide. " $A$ " delivers 1.3 million inkjet cartridges a day, as well as 111,000 printers, 75,000 personal systems and 3,500 servers.

The company's product control technology used to be based on optical barcode reading and, though this is a widely used and low-cost solution, it has its drawbacks, as the reading calls for manual intervention, a line of view and only identifies products in general terms. The new technology now available is RFID - Radio Frequency Identification, which enables one to track products and share supply chain data, automate shipments and receiving, and reduce out-of-stocks in the market, among other benefits. This technology requires no manual intervention, enables reading and writing, and allows individual (serial) identification and the simultaneous reading of multiple labels, which can be associated with other technologies; this, in turn, helps trackability. The RFID operation requires investing in tags, antennae, and a device for receiving information and integrating it into the company's system.

With RFID technology, the solution would consist of recording information electronically on a tag placed directly onto the base of the product, containing the serial number, the part number (product code) and other data, such as the results of the tested product, the product's firmware (identification of the need for rework before the product is delivered to the customer), validity of the cartridges installed and product destination, later linked to the pallet in which the product will be warehoused.

The idea of analyzing the adoption of new technology first arose as a means of improving the storage system, which had certain problems: keyboarding errors (system) of printer lots that were being transferred from the manufacturing area to the warehouses; damaged bar codes that make optical reading difficult; difficulty locating lots that for some reason had been stored in the wrong place; and the complexity of visual selection, given the need to look for digits, among others.

\section{Objectives}

The aim of this paper is to discuss factors that should be taken into account in order to decide whether or not to adopt a new technology. It emphasizes the importance of international cooperation in this process. The methodology used is the case study one, based on "A" decision regarding RFID technology. The study's specific objectives are to:

> Test a conceptual model about technology adoption based on "A" experience;

and

$>$ Explain how international cooperation can contribute to the adoption of innovation, with the participation of partners.

\section{Technological Innovation Adoption}

Innovation can be simply a new way of rethinking the product, i.e., imagining how it could be sold for a lower price (Tucker, 1999). Barbieri (1990), in turn, classifies the different technological innovation levels into: principal, secondary or accessory. Principal innovation concerns the transformation of an invention into products or processes, new or improved. On the other hand, secondary or accessory innovations are the subsequent changes that introduce corrections in the principal innovation and that occur during the experimental or definitive production or sales stages.

Mañas (1993) corroborates this, presenting the different technological innovation strategies adopted by companies, such as: offensive strategies, defensive strategies, imitative strategies, opportunistic strategies and traditional strategies. The offensive strategy is adopted by companies 
that want technical and market leadership, to be achieved through new product launches; they invest a fair amount in research, planning and development, and are quick to explore new opportunities. Major companies can be considered to this profile.

The defensive strategy has the same aims where research, planning and development spending is concerned, but it differs from the former in that it explores opportunities that have already been discovered, thus avoiding high risk. In other words, a defensive strategy capitalizes on the mistakes and achievements of others.

The imitative strategy, which calls for little investment in research, competes in the market by offering the consumer the alternative of low-cost products, whereas the opportunistic strategy aims at identifying opportunities in the environment, taking over market niches, with no investment in research, planning and development. These two profile types are typical of small and medium-sized companies. Last, a traditional strategy, whether explicit or implicit, according to the author, is adopted by companies in mature markets, in which technical changes occur slowly; in this case, the need for innovation is not felt. Here the technological changes boil down to simple design changes applied to existing products and new packaging sizes.

Product or process technological innovation that incorporates new technical, functional or esthetic solutions is very important for companies to maintain their competitiveness under circumstances of constant changes. It can be generated by the innovating company itself, by an external source or by a combination of both.

In deciding whether or not to adopt a technological innovation one must take several factors into account, such as the innovation's attributes, the external environment and the suppliers, as well as organizational characteristics.

The innovation's attributes, according to Rogers (1995), consist of its qualitative relative advantage and the degree to which it is perceived as better than whatever exists already. The relative advantage, from the economic and financial point of view, takes into consideration the expected returns resulting from adopting the innovation.
The compatibility and complexity are linked, respectively, to the viability of the technology that is to be adopted visà-vis. the company's reality and the difficulties of implementing and understanding it. The possibility of trials allows the company to test the technology even before it is definitively adopted. Visibility is the innovation attribute that allows to company to see the results that adopting the technology can provide. Finally, uncertainty, according to Frambach and Schillewaert (1999), is connected with uncertainties as to the benefits and results that adopting the innovation will produce.

As for the external environment, it is important to stress customer focus, communication, reputation and dependence on supplier. The customer focus consists of selecting those potential customers that can make it easier for the market to accept the technology (Frambach and Schillewaert, 1999). According to these authors and to Rogers (1995), broad communication of the technology may be influenced by potential customers and risk reduction may be shared between the integrator and the customer.

Reputation ascribes to the supplier certain characteristics, such as technical competence, perenniality, sustainability of time and public image.

According to Frambach and Schillewaert (1999), network externalities are the number of interrelated organizations in the market that adopted the innovation and that influence others to embrace it as well. Additionally, the competitive pressure for the company to maintain its position in the market may also influence innovation adoption.

The internal social network may generate resistance and/or support for the innovation from informal groups, while the external social network may have a negative or positive influence upon the external networks regarding the adoption (Frambach and Schillewaert, 1999). Rogers (1995) indicate that upper management's willingness helps innovation.

The conceptual model for adoption is presented in a systematic way in Figure $I$ and the variables considered in the adoption of innovation, as dealt with by several authors, are systematized in Exhibit I. 


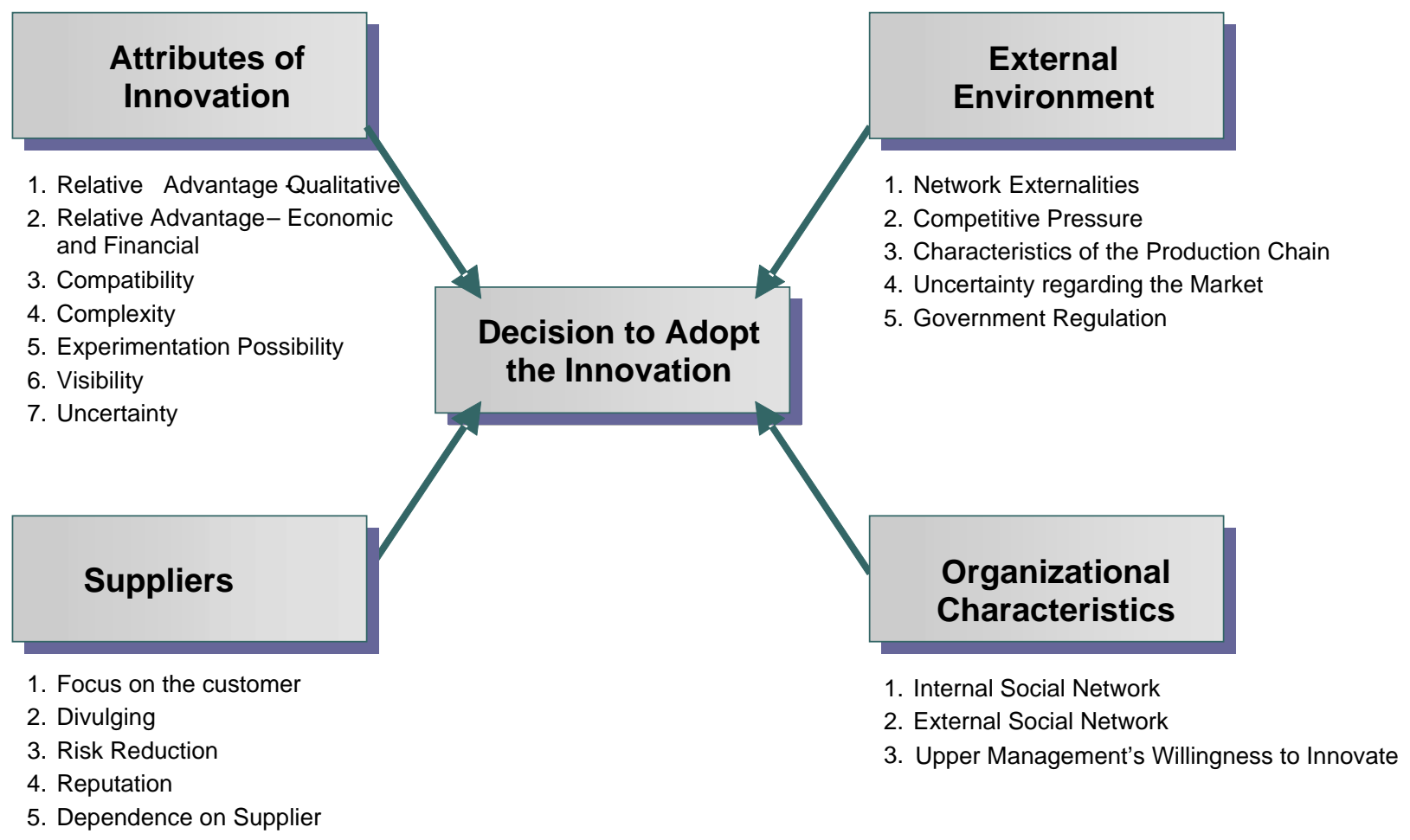

Figure I. Adapted from Vasconcellos (2007).

\begin{tabular}{|c|c|c|}
\hline Variable & Description & Author(s) \\
\hline $\begin{array}{l}\text { Relative Advantage - } \\
\text { Qualitative Aspects }\end{array}$ & $\begin{array}{l}\text { "[...] degree to which an innovation is perceived as better } \\
\text { than the idea it is replacing", including all aspects, other } \\
\text { than the financial ones. }\end{array}$ & $\begin{array}{l}\text { Adapted from } \\
\text { Rogers (1995) }\end{array}$ \\
\hline $\begin{array}{l}\text { Economic and Financial } \\
\text { Aspects }\end{array}$ & $\begin{array}{l}\text { Expectation of financial returns adjusted for innovation } \\
\text { implementation risk. } \\
\text { - Cost of change: new system; training people; stopping } \\
\text { during setup. } \\
\text { - Size of the user unit. }\end{array}$ & $\begin{array}{l}\text { Adapted from } \\
\text { Rogers (1995) }\end{array}$ \\
\hline Compatibility & $\begin{array}{l}\text { "[...] degree to which the innovation is seen as consistent } \\
\text { with the current values, past experiences and needs of the } \\
\text { potential adopters." } \\
\text { - Degree to which the adoption of technology can help } \\
\text { or hinder the company in terms of the possibility of } \\
\text { adopting new technologies, currently being developed. }\end{array}$ & Rogers (1995) \\
\hline Complexity & $\begin{array}{l}\text { "[...] degree to which the innovation is perceived as } \\
\text { difficult to understand and to use" }\end{array}$ & Rogers (1995) \\
\hline Possibility of testing & $\begin{array}{l}\text { "[...] degree to which the innovation can be tested with } \\
\text { some limitations" }\end{array}$ & Rogers (1995) \\
\hline Visibility & $\begin{array}{l}\text { "[...]degree to which an innovation's results are visible to } \\
\text { others" }\end{array}$ & Rogers (1995) \\
\hline Uncertainty & $\begin{array}{l}\text { "Technical uncertainty: the extent to which it is difficult for } \\
\text { a potential adopter to determine how reliable an } \\
\text { innovation is and how well it will function" } \\
\text { "Financial uncertainty: the extent to which the potential } \\
\text { adopter has difficulty determining whether the }\end{array}$ & $\begin{array}{c}\text { Frambach and } \\
\text { Schillewaert (1999) }\end{array}$ \\
\hline
\end{tabular}




\begin{tabular}{|l|l|}
\hline & $\begin{array}{l}\text { implementation of an innovation is financially attractive" } \\
\text { "Social uncertainty: the extent to which it is acceptable } \\
\text { that conflict will occur in the immediate environment of } \\
\text { the potential adopter with regard to the purchase and } \\
\text { implementation of an innovation" (p. 9-10). Frambach, } \\
1999\end{array}$ \\
\hline
\end{tabular}

Component I. Perceived innovation attributes

\begin{tabular}{|c|c|c|}
\hline Variable & Description & Author(s) \\
\hline $\begin{array}{l}\text { Focus on the } \\
\text { Customer }\end{array}$ & $\begin{array}{l}\text { "careful and specific targeting of the innovation towards } \\
\text { selected potential adopters can facilitate acceptance in the } \\
\text { market" (p. 12) }\end{array}$ & $\begin{array}{c}\text { Frambach and } \\
\text { Schillewaert (1999) }\end{array}$ \\
\hline Communication & $\begin{array}{l}\text { "[...] supplier communication activities on the innovation will } \\
\text { not only create awareness of the innovation, }[\ldots] \text { it also } \\
\text { influences the potential customer's perceptions of the } \\
\text { innovation" } \\
\text { Communication channels used (mass / interpersonal) } \\
\text { Efforts of the change agents }\end{array}$ & $\begin{array}{l}\text { Frambach and } \\
\text { Schillewaert (1999) } \\
\text { Rogers (1995) }\end{array}$ \\
\hline Risk Reduction & $\begin{array}{l}\text { "The innovation by be given on trial to the customer for a } \\
\text { certain period of time or the supplier may decide to absorb } \\
\text { major risks of adoption by offering the potential adopter the } \\
\text { innovation at a low introduction price". Frambach, } 1999 \text {. } \\
\text { Sharing the risk with the supplier (investment and loss). } \\
\text { Alliance with the integrator to reduce risk for the customer. }\end{array}$ & $\begin{array}{c}\text { Frambach and } \\
\text { Schillewaert (1999) }\end{array}$ \\
\hline Reputation & $\begin{array}{l}\text { Extent to which one attributes to the supplier characteristics } \\
\text { such as technical competence, perenniality, sustainability over } \\
\text { time, and public image. }\end{array}$ & \\
\hline $\begin{array}{l}\text { Dependence on } \\
\text { supplier }\end{array}$ & $\begin{array}{l}\text { Extent to which the company that adopts the innovation } \\
\text { depends on a single supplier in order to implement it. }\end{array}$ & \\
\hline
\end{tabular}
Component 2. Suppliers

\begin{tabular}{|c|c|c|}
\hline Variable & Description & Author(s) \\
\hline Network externalities & $\begin{array}{l}\text { "The number of other interrelated organizations in the } \\
\text { market environment that have adopted the focal } \\
\text { innovation" }\end{array}$ & $\begin{array}{c}\text { Frambach and } \\
\text { Schillewaert (1999) }\end{array}$ \\
\hline Competitive Pressure & $\begin{array}{l}\text { "In highly competitive markets, innovation adoption may } \\
\text { be necessary to maintain one's market position" (p.l4). } \\
\text { Frambach, } 1999\end{array}$ & $\begin{array}{c}\text { Frambach and } \\
\text { Schillewaert (1999) }\end{array}$ \\
\hline $\begin{array}{l}\text { Production Chain } \\
\text { Characteristics }\end{array}$ & $\begin{array}{l}\text { Distribution of power along the links of the company's } \\
\text { production chain. The decision of one powerful link in the } \\
\text { chain can significantly influence suppliers' or customers' } \\
\text { adoption of innovations, whether upstream or } \\
\text { downstream in the chain. }\end{array}$ & \\
\hline $\begin{array}{l}\text { Uncertainty regarding the } \\
\text { Market }\end{array}$ & $\begin{array}{l}\text { Uncertainty regarding market trends / customer } \\
\text { acceptance of the innovation }\end{array}$ & \\
\hline Goverment Regulation & $\begin{array}{l}\text { "Government regulatory activity, by imposing operational } \\
\text { constraints and costs on industry, often induces a search } \\
\text { for technical alternatives to current practice." }\end{array}$ & \\
\hline
\end{tabular}

\section{Component 3. External Environment}




\begin{tabular}{|c|l|c|}
\hline Variable & \multicolumn{1}{|c|}{ Description } & \multicolumn{1}{|c|}{ Author(s) } \\
\hline $\begin{array}{c}\text { Internal Social } \\
\text { Network }\end{array}$ & $\begin{array}{l}\text { Informal groups' resistance / support of the innovation. } \\
\text { "The interaction, in terms of frequency and richness, between } \\
\text { members of a social system" (p. I3). Participation of } \\
\text { organization members in informal networks. }\end{array}$ & $\begin{array}{c}\text { Adapted from } \\
\text { Frambach and } \\
\text { Schillewaert (I999) }\end{array}$ \\
\hline $\begin{array}{c}\text { External Social } \\
\text { Network }\end{array}$ & $\begin{array}{l}\text { External networks' negative or positive influence upon } \\
\text { adoption. } \\
\text { Interconnectedness: "The degree to which organizations share } \\
\text { information with others" (informal information). }\end{array}$ & $\begin{array}{c}\text { Adapted from } \\
\text { Frambach and } \\
\text { Schillewaert (I999) }\end{array}$ \\
$\begin{array}{c}\text { Upper Management } \\
\text { Willingness to } \\
\text { Innovate }\end{array}$ & $\begin{array}{l}\text { Top management leadership behaviors - "include planning and } \\
\text { communication about change, and developing policies and goals } \\
\text { that support innovation" }\end{array}$ & Rogers (1995) \\
\hline
\end{tabular}

Component 4. Organizational Characteristics

\section{International Innovation Networks and the Choice of Partners}

It is generally believed that it is extremely important for companies to structure evolving means of competing, given the transformations of the markets in which they operate. For Johanson and Vahlne (1977), in Tombi and Moraes (2005), internationalization is the consequence of a process of incremental adjustments that change the company's and the environment's conditions. This exposes the firm to new problems and opportunities.

Schirm (1999, p. 2) states that:

"Internationalization is a process that takes place largely through the interdependence (...) of economic interchange (...) and of the effects of this upon the societies involved. It leads to "the international adoption of dominant economic rationalities, and to the learning (...) of new standards of social behavior and of values, underpinning this process in ideological terms."

The company can enter new markets with the benefit of physical distance or not. The concept of physical distance may be a factor that can benefit or hinder the flow of information between the company and the market; it encompasses factors such as language, political system, educational level and level of industrial development (Andersen, 1992).

Barreto (2002) mentions that multinationals manage a portfolio of several national units thereby creating a strong national presence with responsiveness to national differences. Global companies, on the other hand, treat the global market as an integrated unit. They aim at obtaining cost advantages through centralized global operations. International companies focus on the transfer to and adaptation by external markets of the parent company's know-how and skills. They reflect the standards of exploration of the international product cycle theory.

For Johanson and Vahlne, in Chetty (2004, p. 4), the internationalization process results from a mixture of strategic thinking, strategic action, emerging development, chances and needs. In turn, Bassi (1997) mentions strategies for generating global competitiveness: integration of international activities, international expansion and strategic alliances.

The integration of activities brings about economies of scale and synergies in production, buying, marketing, finance and R\&D (Research and Development). Companies with local operations can integrate their activities into international trade and, to a lesser extent, they can attain this by importing raw materials, components and end products at a lower cost and/or with better quality.

International expansion is connected with companies being players in the international markets through exports, international franchising, and the implementation of units or acquisition of companies abroad. According to the approach proposed by Barkema and Vermeulen (1998, p. 3 ), by acquiring a company one can obtain new technological resources that enable internal development of technological skills. 
Hakansson (1982) and Torelli (1990), in Chetty (2004, p. 4), state that the key resource for gaining access to internationalization is having access to international networks, such as networks of distributors, sub-contracted enterprises, buyers and sellers. Internationalization can benefit from this to the extent that one increases the network's accrual of knowledge.

The international strategic alliances aim at developing formal or informal associations as suppliers of products that offer distinguishing features of a technological nature, with global clients and even with international competitors. Their objectives can be: improving operating efficiency, technological upgrading, expanding sales to the local market by complementing the product portfolio, or increasing international sales.

Lewis (1992):

"In a strategic alliance, the companies cooperate in name of their mutual needs and share risks in order to reach a common objective. Without mutual need, companies may have the same objective, but each one of them can reach it on its own. If they are not exposed to the same significant risks, they cannot expect mutual commitments".

The need for mutual cooperation, mentioned by Lewis (1992), grows in line with the rise of technological interdependence, strengthened by the markets' integration. It enables the gradual expansion of a company's capacity to create products, cut costs, incorporate new technologies, stay ahead of competition, attain the necessary scale for survival in world markets and generate more funds for investing in its basic competencies.

According to Stach (2006), the first stage of the process of choosing partners must consist of selecting the members who can contribute to the company's internal efforts. The second stage is the 'doing' phase; in other words, planning the business's development and selecting the leader that will contact and negotiate with potential business partners; the third and last stage is the value creating phase. Here, it is important for the alliance's management to assume primary responsibility for the coordination of the alliance and to present to the involved parties what one expects to attain through the partnering arrangement.
Persaud et al. (2002) present a conceptual model of synergistic innovative capacity that is influenced by independent constructs and moderating constructs. Synergistic innovative capacity is defined as the ability to create new knowledge or to recombine existing knowledge to create new products, more efficient technology and processes, and to explore the unique capability of each member (partner) around the world. The independent constructs mentioned by the author comprise autonomy, socialization, formalization and communication.

Autonomy is defined as the degree of control over business decision making that can affect the direction and operation of the business among the subsidiaries of a company that operates within a network. Socialization comprises emphasizing the creation of shared objectives, such as targets, values and practices, in order to influence members, so that all have common objectives, which facilitates innovation. Formalization concerns making decisions that are based on a formal system, the establishment of standards and the description of procedures. The communication issue is extremely important so that everyone, regardless of hierarchical level, can be involved with the innovation project and collaborate with it. The moderating constructs encompass cultural diversity, level of resources and environment complexity.

Cultural diversity may generate conflicts, reducing the company's innovative capacity, which in turn can be affected by its level of resources. The environment's complexity, given rapid changes and unstable environment factors, also influences the company's decision to innovate or not.

\section{Research Methodology}

To identify the factors that the company sees as relevant for decision-making with regard to the adoption of technological innovation, we used the exploratory case study method, which has a qualitative and descriptive nature, by interviewing the "A" RFID business manager. To understand the function e functioning of the RFID system, the interviewer visited the company and elaborated a questionnaire to do the interview.

The interview technique enables one to gather data for the qualitative exploratory study. According to Malhotra (200I), a non-structured, direct and personal interview 
allows the only respondent tested by an interviewer to express his motivations, beliefs, attitudes and subjacent sensations about a given topic.

According to Cooper and Schindler (2003), exploratory studies tend to generate loose structures, with the aim of uncovering future research tasks and developing hypothesis and questions for further research. When the researcher attempts to investigate something unknown, regarding whose problems one has no clearly defined notions, exploratory research enables one to develop concepts, establish priorities, develop operating definitions, improve final planning of the research, and save time and money, because, if one finds out that the issue that is the subject of the study is not as relevant as expected, the study can be cancelled.

For Malhotra (200I), exploratory research is used in cases in which it is necessary to define the problem more precisely, identify relevant courses of action or obtain additional data prior to being able to develop an approach. It is characterized by flexibility and versatility with regard to the methods employed, because no formal research procedures or protocols are used.

\section{Brazil's Adoption of RFID Technology}

RFID technology was discovered in 1935 by Robert Alexander Watson-Watt, a Scottish physicist. It was first employed during World War II to identify enemy aircraft. The term RFID - Radio Frequency Identification is the generic expression that applies to remote object identification. The information transmitted by radio waves (with a variety of frequencies and transmission protocols) and that data is usually stored in microchips. This technology provides a method for the identification of articles using radio waves in such a way that a reader communicates with a tag (a label that contains a microchip that retains the information).

RFID has different applications, including tracking objects within the supply chain, monitoring people, verifying authenticity, entertainment (voice activation of toys), security of pharmaceutical instructions, people identification in security areas, electronic engine immobilization, controlling toll booths electronically, high value product identification, and real-time detection of theft, among others. Figure 2 shows the components of an RFID system.

The rising number of studies on RFID applications has gained substantial notoriety in different segments. According to IDTechEx data (2007), one can see the number of studies conducted in different priority segments in different continents.

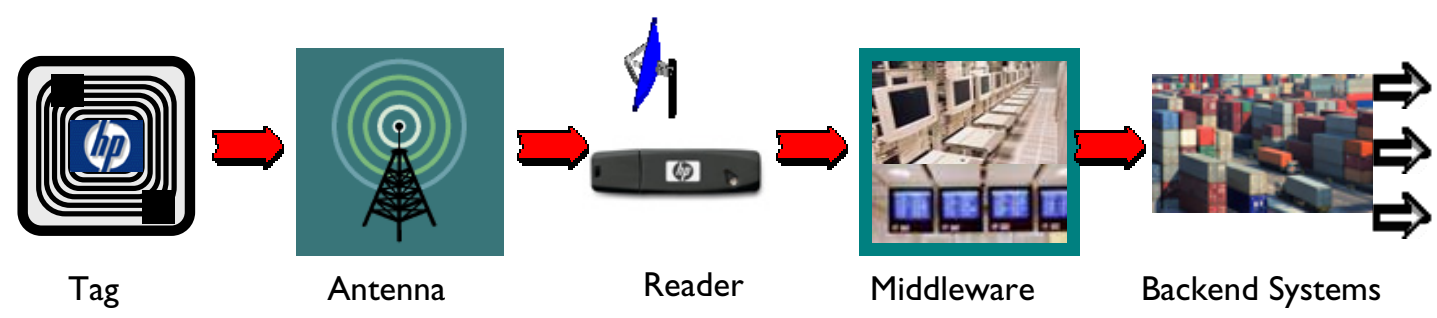

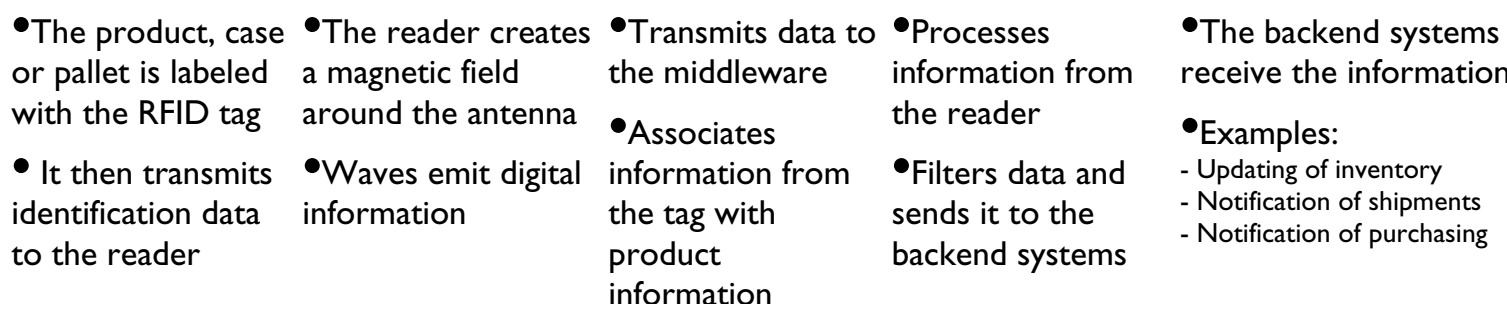

Figure 2. RFID system components. 


\begin{tabular}{|l|c|c|c|c|c|c|}
\hline \multirow{2}{*}{\begin{tabular}{c} 
Continent \\
\cline { 2 - 7 }
\end{tabular}} & $\begin{array}{c}\text { Consumer } \\
\text { goods sales }\end{array}$ & $\begin{array}{c}\text { Financial, } \\
\text { security }\end{array}$ & Logistics & $\begin{array}{c}\text { Transport, } \\
\text { Automotive }\end{array}$ & $\begin{array}{c}\text { Livestock } \\
\text { and Farming }\end{array}$ & $\begin{array}{c}\text { Books, libraries, } \\
\text { files }\end{array}$ \\
\hline $\begin{array}{l}\text { North- } \\
\text { American }\end{array}$ & Ist & 2nd & & & & \\
\hline Asia & & Ist & & 2nd & & \\
\hline Europe & & Ist & 2nd & & & 2nd \\
\hline Australia & & & & & Ist \\
\hline
\end{tabular}

Source: IDTechEx (2007).

Table I. Case study of RFID application by continent

\section{Analysis of the "A" case}

The company's use of RFID arose from the need to produce better results for the firm itself, its partners and its customers. Choice, where implementing the RFID system in Brazil is concerned, was based on selecting a unit with an end-to-end supply chain, i.e., a unit with manufacturing, packaging, distribution and reverse logistics sectors. The factors that the company regarded as relevant for making the decision on whether or not to adopt the new technology are listed below and were based on the previously presented conceptual model (Table 2).

\begin{tabular}{|c|c|c|}
\hline Factors & \multicolumn{2}{|r|}{ "A" Case } \\
\hline \multirow{7}{*}{$\begin{array}{l}\text { Innovation } \\
\text { attributes }\end{array}$} & $\begin{array}{l}\text { Relative } \\
\text { advantages }\end{array}$ & $\begin{array}{l}\text { For each lot that is ready, the reader can automatically register it, rather } \\
\text { than having manual intervention and the risk of errors; } \\
\text { The recording of the serial numbers of export lots can be automated; } \\
\text { Easy identification and localizing in the stock of a specific model ordered } \\
\text { by the customer; } \\
>\text { Easy identification of products stocked in the wrong place; } \\
>\text { Easy identification and localizing of cases that have been in stock for } \\
\text { longer; } \\
\text { "A"'s and distributors' distribution centers can use the tags in their } \\
\text { warehouses; } \\
>\quad \text { Reduction of stock management costs, subject to the costs of RFID } \\
\text { implementation and maintenance being lower. }\end{array}$ \\
\hline & $\begin{array}{l}\text { Compatibility } \\
\text { with the } \\
\text { current system }\end{array}$ & $\begin{array}{l}\text { Need to implement customizations to enable integration with the } \\
\text { company's systems: manufacturing ERP, company-wide ERP (SAP). }\end{array}$ \\
\hline & $\begin{array}{l}\text { Level of } \\
\text { complexity }\end{array}$ & High, because the technology is new. \\
\hline & Visibility & $\begin{array}{l}\text { Improved on-shelf product availability; } \\
\text { Better quality due to shorter product stocking time; faster maintenance } \\
\text { thanks to easier locating of product 'record' with information about it; } \\
\text { The customers can use the tags if they have an RFID system. }\end{array}$ \\
\hline & $\begin{array}{l}\text { Degree of } \\
\text { uncertainty }\end{array}$ & High, as the technology is new. \\
\hline & Reputation & $>$ Equipment suppliers not well known (emerging companies); \\
\hline & Risk reduction & $\begin{array}{l}\text { The implementation of a technological cooperation system with nine } \\
\text { suppliers from six different countries reduced the risk; }\end{array}$ \\
\hline
\end{tabular}




\begin{tabular}{|c|c|c|}
\hline $\begin{array}{l}\text { Technology } \\
\text { Suppliers }\end{array}$ & $\begin{array}{l}\text { Dependence } \\
\text { on supplier }\end{array}$ & There were no problems, as the activities were conducted in partnership. \\
\hline \multirow{3}{*}{$\begin{array}{c}\text { External } \\
\text { Environment }\end{array}$} & $\begin{array}{l}\text { Adoption by } \\
\text { competition }\end{array}$ & $\begin{array}{l}\text { The competition does not generate a need for the technology, as it is new, } \\
\text { but customers increasingly demand a shorter delivery time, a higher quality } \\
\text { and a lower price; }\end{array}$ \\
\hline & Regulation & $\begin{array}{l}\text { In Brazil, there is a dedicated frequency band, as established by Anatel, } \\
\text { Brazil's National Telecommunications Agency, but in other countries this } \\
\text { could become a barrier; }\end{array}$ \\
\hline & $\begin{array}{l}\text { Production } \\
\text { chain }\end{array}$ & $\begin{array}{l}\text { Bargaining power was important in the Wal-Mart case. The potential for } \\
\text { chain integration is a plus; }\end{array}$ \\
\hline \multirow{3}{*}{$\begin{array}{l}\text { Organization } \\
\text { al } \\
\text { characteristic } \\
\quad \text { s }\end{array}$} & $\begin{array}{l}\text { Upper } \\
\text { management's } \\
\text { willingness to } \\
\text { innovate }\end{array}$ & $\begin{array}{l}\text { A company with an innovative culture and the actual support of its upper } \\
\text { management, both in Brazil and in the USA; }\end{array}$ \\
\hline & $\begin{array}{l}\text { Internal social } \\
\text { network }\end{array}$ & Some resistance to change was encountered and had to be managed; \\
\hline & $\begin{array}{l}\text { External social } \\
\text { network }\end{array}$ & $\begin{array}{l}\text { Establishment of a multi-functional group involving several "A's" units } \\
\text { worldwide for the execution of the RFID implementation project at "A" } \\
\text { Brazil, benefiting adoption of the technology from the international point } \\
\text { of view. }\end{array}$ \\
\hline
\end{tabular}

Table 2. Brazil case results, based on the conceptual model.

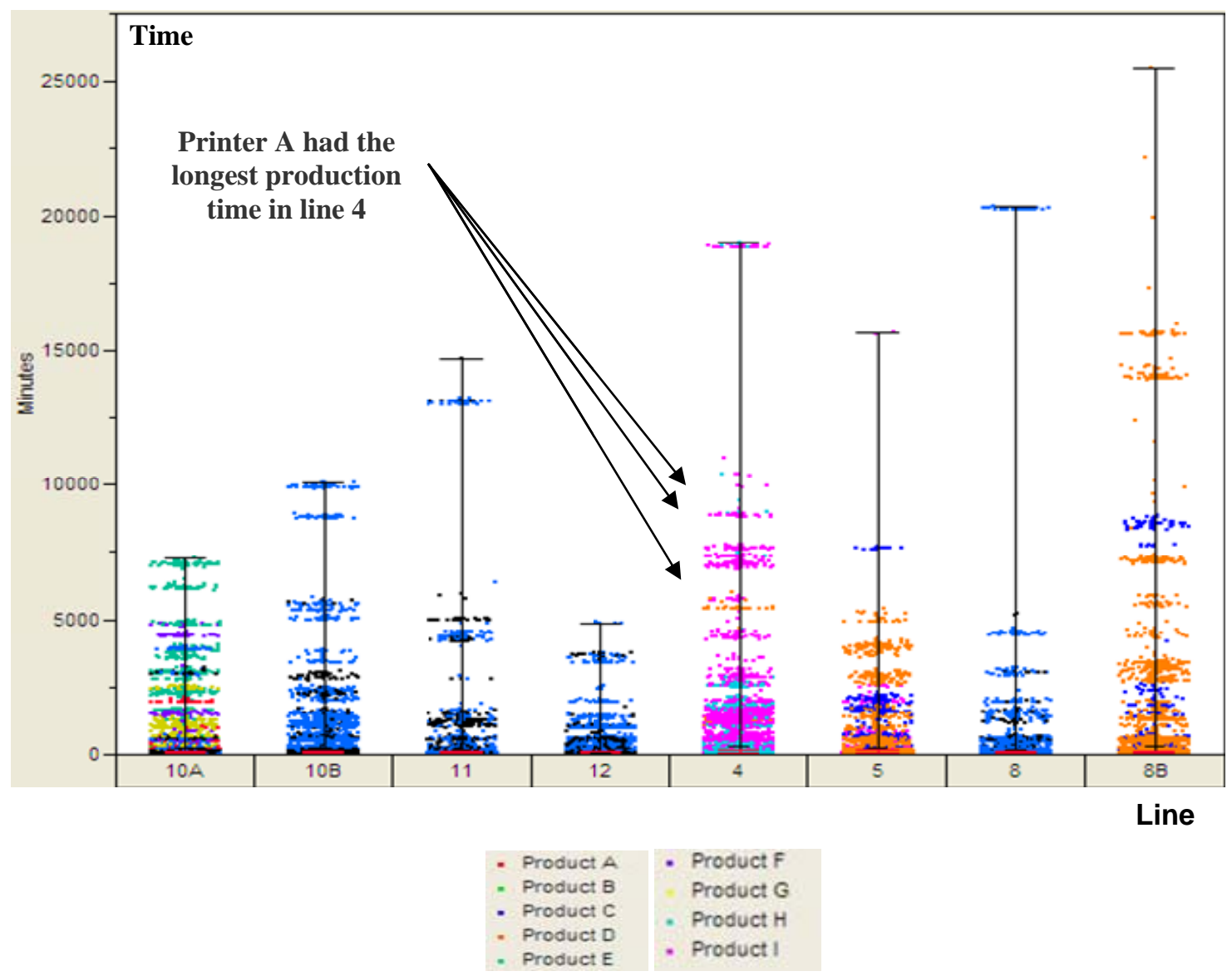

Graph I. Product production time, by line 
The benefits obtained from adopting RFID technology provided a visibility increase in the entire supply chain, process improvements, a reduction of manufacturing time, and improved data reliability over the full chain.

Graph I, based on the data obtained from the production process, shows each product's production time by production line. This allows one to identify which product took longer to be processed in each line. In this case, one can see that product $A$ took the longest to be produced in line 4 , the product $B$ took the longest to be produced in line $8 \mathrm{~B}$ and the product $\mathrm{E}$ took the longest to be produced in line IOA. The graph made it possible to identify manufacturing bottlenecks.

\section{International Cooperation as a Success Factor}

To transfer the technology, it was necessary to engage in technological cooperation. As the technology was new, cooperation enabled knowledge sharing and helped to reduce risk.

Within this context, nine different partners from various countries took part in the RFID system implementation project, including: manufacturing, logistics, a chips provider, an intelligent tags provider, an RFID reader provider, an RFID control system provider, a project management resources provider, an RFID statistical analyses provider and a research institute. Each of these partners had different functions in the RFID technology implementation project (Figure 3):

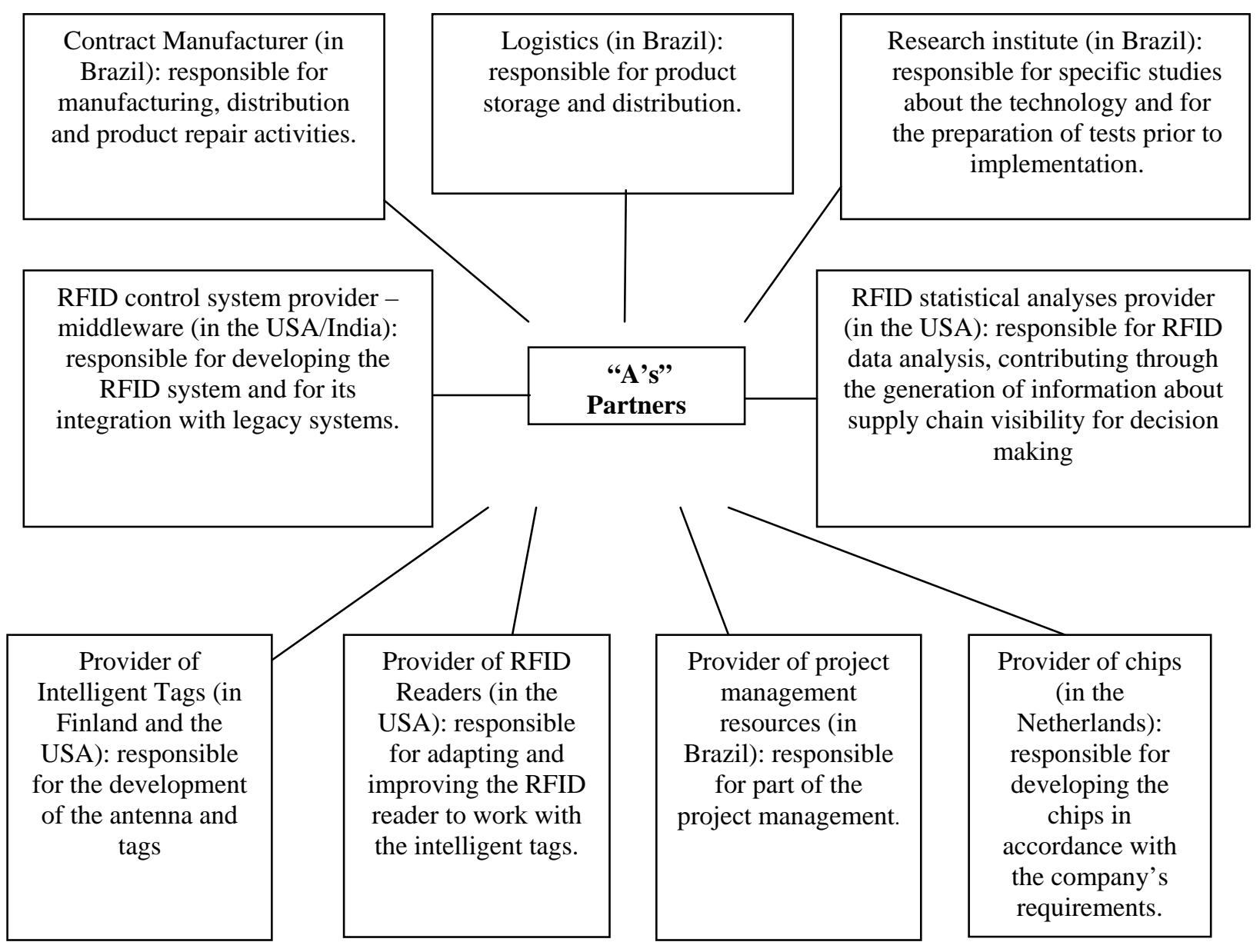

Figure 3. "A's" technological partners 


\section{Results of New Technology Adoption and Final Thoughts}

The company's adoption of RFID technology provided supply chain improvements overall and particularly in the production and stock control areas. For making the decision on whether or not to adopt the RFID system were based on the factors of the conceptual model that allowed the study directed in the attributes of the innovation, suppliers, external environment and organizational characteristics. The benefits gotten with RFID system follow below:

Production: In "A's" production section there was an improvement in processes and reduction of the manufacturing time, because RFID technology allowed the company to identify and solve manufacturing bottlenecks. Furthermore, the visibility of the product flow along the supply chain improved; additionally, chain data reliability improved.

Stock control: Adopting RFID technology for stock improved inventory control, product distribution, service to retailers and distributors, replenishment of retail product and the execution of promotions, in addition to reducing errors due to manual recording of data, as was the case previously. It is important to highlight that when deciding whether or not to adopt a new technology, one must take into account that it is recent (concept trial); that one is not dealing only with technology, but will also have to review processes; that interoperability and lack of visual contact may prove to be a challenge; and that the company must be prepared to collect a large quantity of data.

International cooperation network: International cooperation among different partners makes it possible to attain satisfactory results more precisely and allows one to reduce risks. In choosing partners, it is necessary to identify the relevant factors for the partnership to be as successful as expected. These factors include: Global EPC membership, in order to better understand the requirements of the business for implementation and better influence development and progress through technical integration; partners of other RFID partners; partners that have robust industrial equipment; partners that are involved in other pilot projects, so that they can clearly present a case study; partners that are able to conduct validations and verifications without user intervention; partners that have consultants for training, integration and implementation; and partners who present equipment that is largely integrated with supply chain software and other company programs, among others.

Setting up a multifunctional group that included several "A" units around the world in order to execute the project of implementing RFID at "A"-Brazil was essential for the new technology's success.

One should stress that the conceptual model was useful for understanding "A's" decision process where adoption of the innovation is concerned; however, other studies will be required, as the model was tested with just one case.

\section{Bibliographic References}

ANDERSEN, O. (1992). On the Internationalization Process of Company's: A Critical Analysis. Journal of International Business Studies, Second Quarter.

BARBIERI, J. (1990). Produção e transferência de tecnologia. Ática, São Paulo.

BARKEMA, H., Vermeulen, F. (1998). International Expansion through Start-Up or Acquisition: A Learning Perspective. Academy of Management Journal, $4 \mathrm{I}$ (I).

BARRETO, A. (2002). A internacionalização da companhia sob o enfoque dos custos de transação. In: ÂNGELA DA ROCHA (2002). A internacionalização das companhias brasileiras. Mauad, Rio de Janeiro.

BASSI, E. (1997). Globalização de Negócios. Cultura Editores Associados, São Paulo.

CHETTY, C., Campbell-Hunt, C. (2004). A Strategic Approach to Internationalization: A Traditional Versus a "Born-Global" Approach. Journal of International Marketing, I2(I).

COOPER, D., Schindler, P. (2003). Métodos de Pesquisa em Administração. Bookman, Porto Alegre.

FRAMBACH, R., Schillewaert, N. (1999). Organizational innovation adoption: A multi-level framework of determinants and opportunities for future research. Institute for the Study of Business Markets, Pennsylvania State University, USA. 
IDTechEx (2007). RFID - A Tale of Four Continents. http://www.idtechex.com/products/en/articles/000005I5.as p [Accessed Nov. 6, 2007].

LEWIS, J. (1992). Alianças Estratégicas - Estruturando e Administrando Parcerias para o Aumento de Lucratividade. Editora Pioneira, São Paulo.

MALHOTRA, N. (200I). Pesquisa de Marketing: Uma Orientação Aplicada. Bookman, Porto Alegre.

MAÑAS, V. (1993). Gestão de tecnologia e inovação. Érica, São Paulo.

OVIATT, B. , McDougall, P. (2005). Defining International Entrepreneurship and Modeling the Speed of Internationalization. Entrepreneurship: Theory \& Practice, 29(5), $537-553$.

PERSAUD, A., Kumar, U., Kumar, V. (2002). Coordination Structures and Innovative Performance in Global R\&D Labs. Canadian Journal of Administrative Sciences. March, pg. 57.

ROGERS, E. (1995). Diffusion of Innovations. The Free Press, New York.

SCHIRM, S. (1999). Mercados Globais e Margem de Ação do Estado. Konrad Adenauer Stiftung, São Paulo.

STACH, G. (2006). Special section on innovation. Business alliances at Eli Lilly: a successful innovation strategy. Strategy \& Leadership. 34(5), 28-33.

TOMBI, W., Moraes, M. (2005). Expandindo Rumo a Mercados Internacionais: O Caso Weg. In SIMPOI (2005). Simpoi Anais Proceedings, São Paulo.

TUCKER, R. (1999). Agregando valor ao seu negócio. Makron Books, São Paulo. 